\title{
Effects of Coffee Intake on Oxidative Stress During Aging-related Alterations in Periodontal Tissue
}

\author{
TERUMASA KOBAYASHI ${ }^{1}$, TAKAYUKI MARUYAMA ${ }^{2}$, TOSHIKI YONEDA ${ }^{1}$, \\ HISATAKA MIYAI ${ }^{1}$, TETSUJI AZUMA ${ }^{3}$, TAKAAKI TOMOFUJI ${ }^{3}$, \\ DAISUKE EKUNI ${ }^{1}$ and MANABU MORITA ${ }^{1}$ \\ ${ }^{1}$ Department of Preventive Dentistry, Okayama University Graduate School of Medicine, \\ Dentistry and Pharmaceutical Sciences, Okayama, Japan; \\ ${ }^{2}$ Center for Innovative Clinical Medicine, Okayama University Hospital, Okayama, Japan; \\ ${ }^{3}$ Department of Community Oral Health, Asahi University School of Dentistry, Mizuho, Japan
}

\begin{abstract}
Background/Aim: The purpose of this study was to determine the anti-aging effects of coffee intake on oxidative stress in rat periodontal tissue and alveolar bone loss. Materials and Methods: Male Fischer 344 rats ( 8 weeks old) were randomized to four groups; the baseline group immediately sacrificed, the control group fed with normal powdered food for 8 weeks, and the experimental groups fed with powdered food containing $0.62 \%$ or $1.36 \%$ coffee components for 8 weeks. Results: Alveolar bone loss and gingival level of 8-hydroxydeoxyguanosine were significantly lower in the $1.36 \%$ coffee group than in the control group. Nuclear factor erythroid 2-related factor 2 translocation to the nucleus was significantly higher in the $1.36 \%$ coffee group than in the control group. Conclusion: Continuous intake of $1.36 \%$ coffee could prevent age-related oxidative stress in the periodontal tissue and alveolar bone loss, possibly by up-regulating the Nrf2 signaling pathway.
\end{abstract}

Aging is defined in biological terms as an age-dependent decline in physiological function (1) and characterized by an increased risk of age-associated diseases and death. One potential cause of aging is mitochondrial dysfunction and oxidative damage $(2,3)$. Biosynthesis, oxidative phosphorylation ability, and other activities of mitochondria decline with aging, and mitochondrial DNA damage, apoptosis

This article is freely accessible online.

Correspondence to: Takayuki Maruyama, Center for Innovative Clinical Medicine, Okayama University Hospital, 2-5-1, Shikata-cho, Kita-ku, Okayama 700-8558, Japan. Tel: +81 862356712, e-mail: t-maru@md.okayama-u.ac.jp

Key Words: Aging, coffee, oxidative stress, antioxidant, periodontal tissue. induction and production of reactive oxygen species (ROS) progressively increase $(4,5)$. Dysfunction of the mitochondrial electron transport system leads to increased ROS production, which is considered as an important factor in accelerating the aging process (6). Therefore, reducing ROS via antioxidant agents might help suppress the aging process.

Aging is closely associated with alveolar bone loss (ABL); odds ratios (OR) range from 1.72 for 35-44-year-old persons to 9.01 for $65-74-y e a r-o l d s ~(7)$. The fact that ROS play a role in periodontal tissue destruction has also been identified (810). On the other hand, animal and clinical studies have found that antioxidant agents can help prevent periodontal disease $(11,12)$. These studies focused on the effects of short-term antioxidant agent intake on periodontal disease. However, the effects of continuous intake of antioxidant agents on aging over the longer term remain unclear.

Coffee is a popular beverage consumed in many countries and its ingredients have a powerful antioxidant capacity (13). An animal study showed that coffee improved liver oxidative balance in rats fed high fat diet (14). Also, an epidemiological study has found an inverse association between coffee consumption and severe periodontitis (15). On the other hand, some studies showed that coffee and some of its components might have detrimental effects on periodontal tissues (16-18). The mechanism through which coffee components affect the aging of periodontal tissue is unknown.

Herein, we postulated that coffee intake would suppress agerelated oxidative stress in periodontal tissue and ABL. Therefore, the purpose of this study was to evaluate the effects of coffee intake on oxidative stress in rat periodontal tissue and ABL.

\section{Materials and Methods}

Animals. Male Fischer 344 rats ( 8 weeks old, $\mathrm{n}=32$ ) were used in this study. The rats were housed in an air-conditioned room (23$25^{\circ} \mathrm{C}$ ) with a $12 \mathrm{~h}$ light-dark cycle. The experiments were performed in accordance with the institutional guidelines of the Animal Care 
and Use Committee, Okayama University (OKU-2016248) according to the ARRIVE and 3Rs statements.

Experimental design. The rats were randomly assigned to four groups ( $\mathrm{n}=8$ each). The baseline group was immediately sacrificed and the control group was fed with MF normal powdered food (Oriental Yeast Co. Ltd., Osaka, Japan) for 12 weeks. The experimental groups $(0.62 \%$ and $1.36 \%$ coffee groups $)$ were fed with MF normal powdered food containing $0.62 \%$ or $1.36 \%$ freezedried, powdered coffee components (Nescafé Excella L906320:16; Nestlé Japan Ltd., Kobe, Japan) for 12 weeks, respectively (19). This coffee component contains $150 \mathrm{mg} / \mathrm{g}$ polyphenol, and the proportion of chlorogenic acid in the polyphenol is $15 \%$.

The rats were euthanized under isoflurane inhalation at the conclusion of the 12-week experimental period. The right maxillary molar regions were resected en bloc, fixed in Bouin's fluid for one day and decalcified with $10 \%$ tetrasodium-EDTA aqueous solution $(\mathrm{pH}$ 7.4) at room temperature for two weeks for histological analysis. Gingival biopsy samples of the left maxillary molar regions were homogenized using a frozen cell crusher (Microtec Co., Chiba, Japan) for real-time polymerase chain-reaction (PCR) investigations. The right mandibular regions were resected to measure alveolar bone loss. Serum was separated by centrifugation from cardiac blood at $1,500 \times g$ for $15 \mathrm{~min}$ and stored at $-80^{\circ} \mathrm{C}$.

Measurements of serum oxidative stress and antioxidant capacity. Serum levels of reactive oxygen metabolites (ROM) and total antioxidant capacity were determined by spectrophotometry using a Free Radical Elective Evaluator (Diacron International, Grosseto, Italy) as described $(9,20)$. Serum levels of ROM are markers of circulating ROS, which are expressed in Carratelli units (CARR U). One CARR U corresponds to $0.08 \mathrm{mg} / \mathrm{dl}$ hydrogen peroxide. The OXY-adsorbent test evaluates the capacity of serum to counteract the oxidative action of hypochlorous acid $(\mathrm{HClO})$, and results are expressed as micromoles of $\mathrm{HClO}$ consumed by $1 \mathrm{ml}$ of test sample $(\mu \mathrm{mol} \mathrm{HClO} / \mathrm{ml})$.

Histological and immunohistochemical analyses. Bucco-palatal sections ( $2 \mu \mathrm{m}$ thick) were dehydrated with ethanol, immersed in xylene and embedded in paraffin, then stained with hematoxylin and eosin (HE) or immunostained for 8-hydroxydeoxyguanosine (8OHdG) using a commercial kit (Histofine Simple Stain MAX PO; Nichirei Co., Tokyo, Japan). The hydroxyl product of deoxyguanosine produced by oxidative stress, $8-\mathrm{OHdG}$, is generally regarded as a reliable indicator of oxidative stress $(10,21)$. Polyclonal antibodies against 8-OHdG (Chemicon International, Temecula, CA, USA) were diluted 1:200 in phosphate buffered saline. The sections were placed in 3-3'-diaminobenzidine tetrahydrochloride for color development and then counterstained with Mayer's hematoxylin.

Histological measurements were performed using a×400 microscope. 8 -OHdG positive cells and total cells were counted in standard areas $(0.1 \mathrm{~mm} \times 0.1 \mathrm{~mm}$ each) within the gingiva (the connective tissues subjacent to the junctional epithelium) and periodontal ligament (22). Intra-examiner reproducibility was confirmed by double-scoring 10 randomly selected sections at two-week intervals. Intra-examiner agreement for 8 -OHdG-positive cells was $>80 \%$.

Measurements of alveolar bone loss. Right mandibular regions were de-fleshed using curettes, stained with $1 \%$ aqueous methylene blue (Sigma, St. Louis, MO, USA) for five minutes and photographed using a digital camera (Nikon Instruments Inc., Tokyo, Japan). The distance (in $\mathrm{mm}$ ) from the cement-enamel junction (CEJ) to the alveolar bone crest (ABC) of the first molars (three roots) were determined by image analysis using ImageJ software $(\mathrm{NIH}$, Bethesda, MD, USA). The average ABL at three points was defined as reflecting the amount of alveolar bone loss (23).

Gene expression analysis using real-time reverse transcriptionpolymerase chain reaction array (RT-PCR array). Total RNA was extracted from pooled gingival samples ( $n=3$ per group) using the TRI reagent (Molecular Research Center Inc., Montgomery, OH, USA). The purity of the RNA samples (A260/A230 ratio, >1.8; A260/A280 ratio, 1.8-2.0) and concentrations (>100 $\mathrm{ng} / \mu \mathrm{l})$ were confirmed and then the RNA was reverse transcribed. First-strand complementary DNA was prepared from total RNA $(0.8 \mu \mathrm{g})$ using the RT2 FirstStrand Kit (Catalogue no., 330401; Qiagen, Hilden, Germany). The reverse transcription reaction proceeded at $37^{\circ} \mathrm{C}$. In brief, $0.8 \mu \mathrm{g}$ of total RNA was added to $2 \mu$ of Buffer GE ( $5 \AA \AA \sim$ gDNA Elimination Buffer), and the final volume was adjusted to $10 \mu \mathrm{l}$ with RNase-free water. The mixture was denatured at $42^{\circ} \mathrm{C}$ for $5 \mathrm{~min}$, cooled on ice for 60 seconds and reverse transcribed after adding $10 \mu$ of reverse transcription mix to the solution. The reaction mixture was incubated at $42^{\circ} \mathrm{C}$ for $15 \mathrm{~min}$, and then terminated by heating at $95^{\circ} \mathrm{C}$ for $5 \mathrm{~min}$. The cDNA samples generated $(20 \mu \mathrm{l})$ were then diluted with $91 \mu \mathrm{l}$ of RNase-free water and stored at $-20^{\circ} \mathrm{C}$. Real-time PCR proceeded using a Rotor-Gene 6000 Real-Time PCR detection system (Qiagen). Gene expression was examined using the Rat Oxidative Stress and Antioxidant Defense RT2 Profiler ${ }^{\mathrm{TM}}$ PCR Array (Qiagen). The expression of 84 different genes was targeted for detection by realtime PCR. The RT2 Profiler ${ }^{\mathrm{TM}}$ PCR Array includes integral undercoating primers for 84 tested and 5 housekeeping genes as well as positive control elements to determine the efficiency of the reverse transcription reaction, the capacity of the PCR reaction, and detection of genomic DNA contamination. The PCR mixture for 100 reactions contained 1,150 $\mu \mathrm{l}$ of SYBR Green ROX FAST Mastermix (Qiagen), $102 \mu \mathrm{L}$ of cDNA template, and 1,048 $\mu \mathrm{l}$ of RNase-free water. The PCR reaction mix was added to the wells of the PCR plate in equal amounts $(20 \mu \mathrm{l})$, then the real-time PCR cycling program of $10 \mathrm{~min}$ at $95^{\circ} \mathrm{C}$ and 40 cycles of denaturation at $95^{\circ} \mathrm{C}$ for $15 \mathrm{~s}$ recommended by the plate manufacturer for Rotor-Gene 6000 was followed by annealing for $30 \mathrm{~s}$ and elongation at $60^{\circ} \mathrm{C}$. Melting curves were subsequently analyzed using Rotor-Gene Q (version 2.1.0; Qiagen) software. Fold changes in each gene in the $1.36 \%$ coffee group were compared with gene expression by the control group.

Histological evaluation of nuclear factor erythroid 2-related factor 2 (Nrf2) translocation. We double-stained tissue sections with fluorescence to confirm Nrf2 translocation to the nucleus. Antigen was retrieved using Histo VT One (Nacalai Tesque, Kyoto, Japan) at $98^{\circ} \mathrm{C}$ for $40 \mathrm{~min}$ followed by incubation for $20 \mathrm{~min}$ at room temperature. A polyclonal antibody against Nrf2 (Santa Cruz Biotechnology Inc., Dallas, TX, USA) was diluted to 1:500 in phosphate-buffered saline (3). The secondary antibody was 1:250diluted Alexa Fluor 594-conjugated anti-rabbit IgG (Thermo Fisher Scientific, Kanagawa, Japan), which produces red fluorescence with excitation and emission maxima of 561 and about $594 \mathrm{~nm}$ respectively (24). Thereafter, the slides were covered with 4', 6diamidino-2-phenylindole (DAPI) mounting medium (ImmunoSelect Antifading Mounting Medium; Dianova, Hamburg, Germany), which produces blue fluorescence with excitation and emission maxima of 365 and about $460 \mathrm{~nm}$, respectively (25). 
A

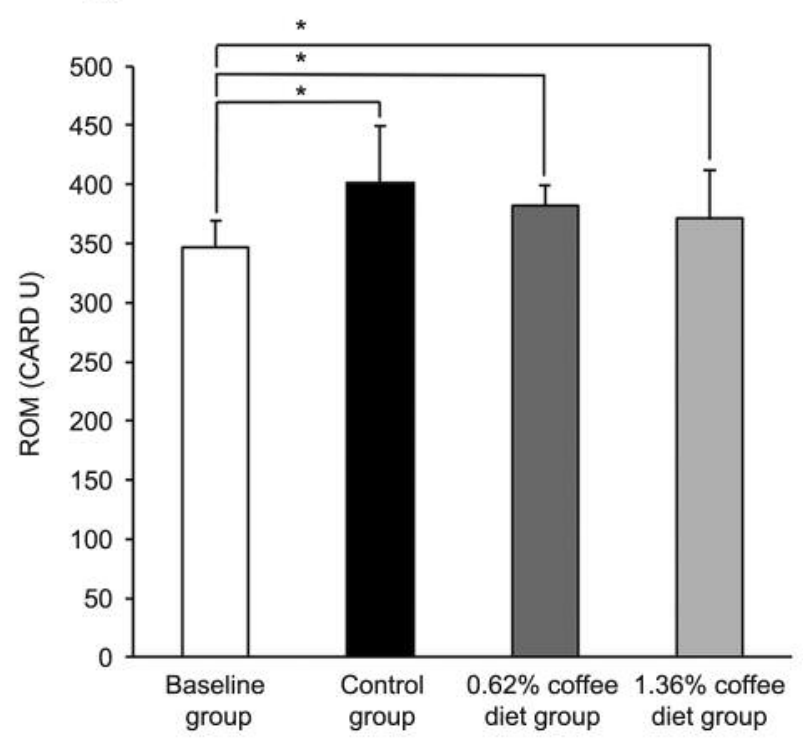

B

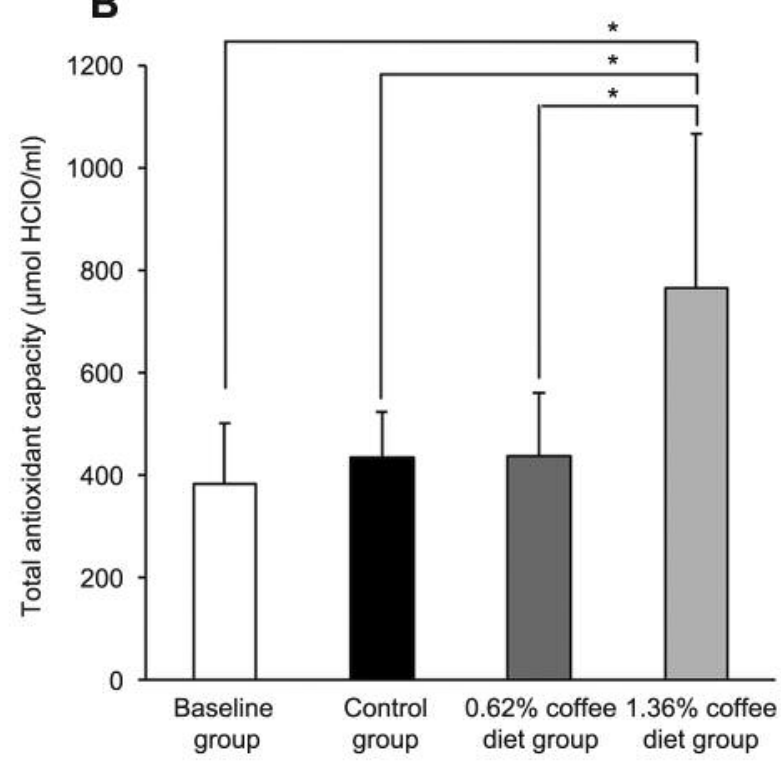

Figure 1. Serum levels of ROM (A) and total antioxidant capacity (B). Bars represent mean $\pm S D(* p<0.05$, according to one-way ANOVA followed by Tukey's method).

Statistical analysis. The data are presented as the mean values \pm standard deviation. The significance of differences between the groups was evaluated by one-way ANOVA followed by Tukey's method or Student's $t$-test using a statistical software package (SPSS version 22.0; IBM, Tokyo, Japan). The level of significance was set at $p<0.05$. Intra-examiner agreement was more than $80 \%$ in all experimental procedures.

\section{Results}

Food consumption did not significantly differ between the control and coffee groups during the experimental period (data not shown). Also, the average body weight did not significantly differ among three groups at baseline and after 12 weeks (control group; $174.8 \mathrm{~g}$ and $307.0 \mathrm{~g}, 0.62 \%$ coffee group; $177.2 \mathrm{~g}$ and $315.5 \mathrm{~g}, 1.36 \%$ coffee group; $171.6 \mathrm{~g}$ and $311.1 \mathrm{~g}$, respectively).

Serum levels of ROM were significantly lower in the baseline group than in all other groups $(p=0.023)$. Serum levels of ROM were lower in the $0.62 \%$ and $1.36 \%$ coffee groups than in the control groups, but the differences did not reach significance (Figure 1A). On the other hand, serum levels of total antioxidant capacity were significantly higher in the $1.36 \%$ coffee group than in the baseline, control and $0.62 \%$ coffee groups $(p=0.001,0.005$ and 0.005 , respectively; Figure 1B).

The ratios of $8-\mathrm{OHdG}$-positive cells to total cells were significantly higher in periodontal tissues from the control, than the baseline group $(p<0.001)$. The ratios of $8-\mathrm{OHdG}-$ positive cells to total cells in the gingival tissue in the $1.36 \%$ coffee group were significantly lower than those in the control and $0.62 \%$ coffee groups $(p=0.001$ and 0.018 , respectively; Figure 2).

The mean gap between the CEJ and the $\mathrm{ABC}$ was significantly greater in the control than in the baseline group $(p<0.001)$, and that between CEJ and the ABC was significantly lower in the $1.36 \%$ coffee group than in the control group ( $p=0.001$; Figure 3$)$.

RT-PCR analysis identified three genes with over a two-fold increase in expression in the $1.36 \%$ coffee group compared with the control group. Glutamate cysteine ligase modifier subunit, ferritin, and hypoxanthine phosphoribosyltransferase 1 mRNA values were elevated (Table I).

Nuclear levels of Nrf2 were significantly higher in the $1.36 \%$ coffee group than in the control group according to nuclear translocation assays ( $p=0.008$; Figure 4$)$.

\section{Discussion}

To the best of our knowledge, this is the first study to investigate the effects of continuous coffee intake on gingival oxidative stress and ABL in rats. The ratios of $8-\mathrm{OHdG}-$ positive to total cells in periodontal tissues were significantly higher in the control group at 20 weeks of age than in the baseline group at 8 weeks of age. Since $8-\mathrm{OHdG}$ is a parameter of oxidative DNA damage $(10,21)$, these findings indicated that oxidative stress in periodontal tissue increases 

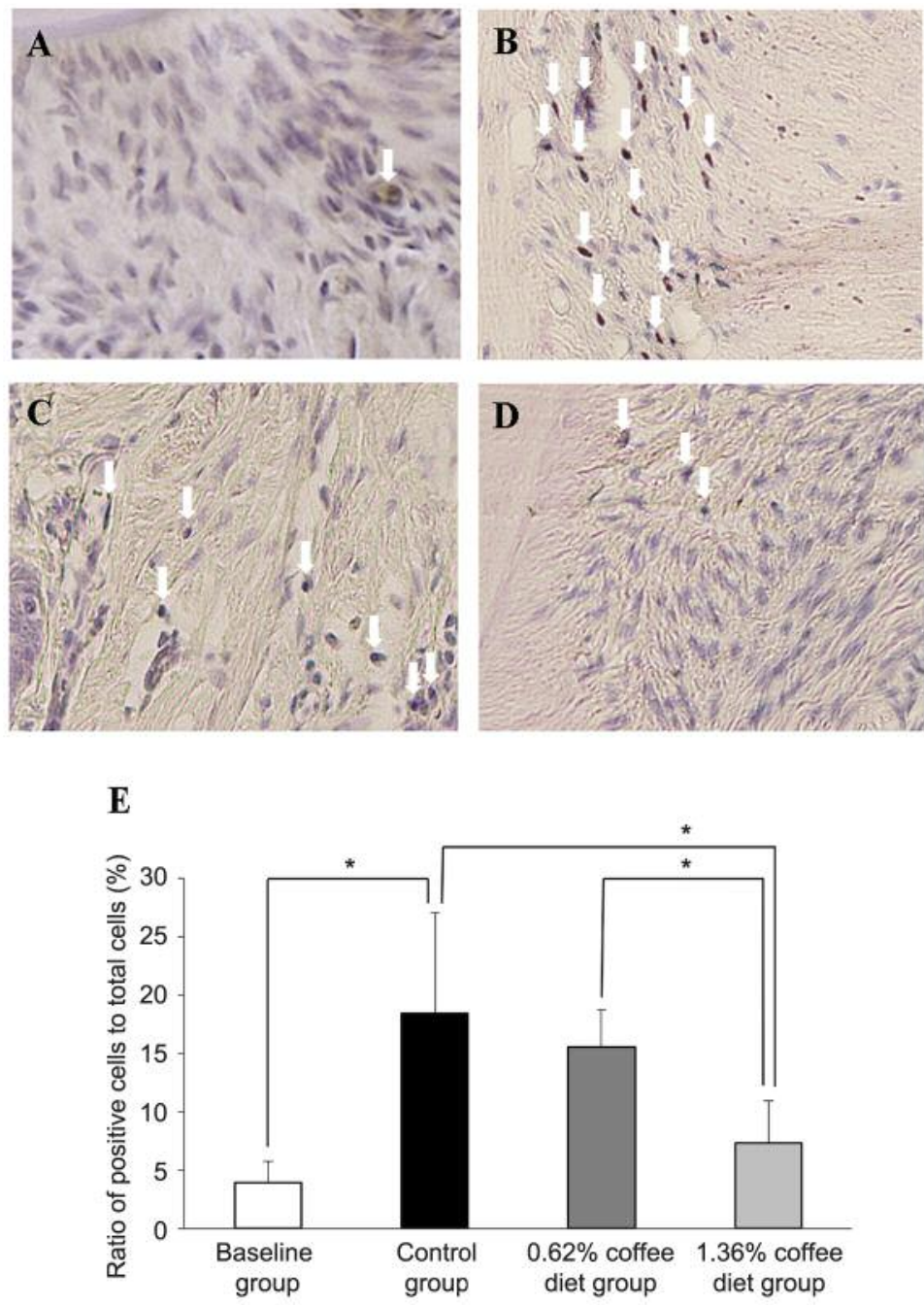

Figure 2. 8-OHdG-positive cells (white arrows) in the gingival tissue (A: Baseline group, B: Control group, C: 0.62\% coffee diet group, D: 1.36\% coffee diet group). Ratios of 8-OHdG-positive cells to total cells $(E)$. Bars represent mean $\pm S D(* p<0.05$, according to one-way ANOVA followed by Tukey's method).

with aging. In contrast, the ratios of $8-\mathrm{OHdG}$-positive to total cells in the periodontal tissue were significantly lower in the $1.36 \%$ coffee group than in the control group. Serum values for total antioxidant capacity were significantly higher in the $1.36 \%$ coffee group than in the control group. Continuous intake of a diet containing $1.36 \%$ coffee might reduce agerelated oxidative stress in periodontal tissues by increasing systemic antioxidant capacity.

Serum levels of ROM were significantly higher in the control, than in the baseline group, indicating that systemic oxidative stress increases with aging. In contrast, serum levels of ROM were concentration-dependently lower in the $0.62 \%$ and $1.36 \%$ coffee groups than in the control group, but the differences did not reach statistical significance. A previous study identified a significant reduction in serum
ROM in rats after continuous intake of hydrogen-rich water for $>10$ months (26). Our model involved continuous coffee intake for 12 weeks, which might have been insufficient to reduce systemic oxidative stress.

The distance from the CEJ to the ABC was significantly greater in the control group at 20 weeks of age compared to the baseline group at 8 weeks of age, and significantly lower in the $1.36 \%$ coffee group than in the control group. Oxidative stress in periodontal tissues is involved in the progression of alveolar bone loss $(27,28)$. Previous studies have revealed that endothelial nitric oxide synthase, which is synthesizes nitric oxide, regulates osteogenesis by activating osteoblasts $(29,30)$. Nitric oxide is a free radical with a powerful oxidative effect. We did not determine nitric oxide levels here, but continuous intake of $1.36 \%$ coffee 


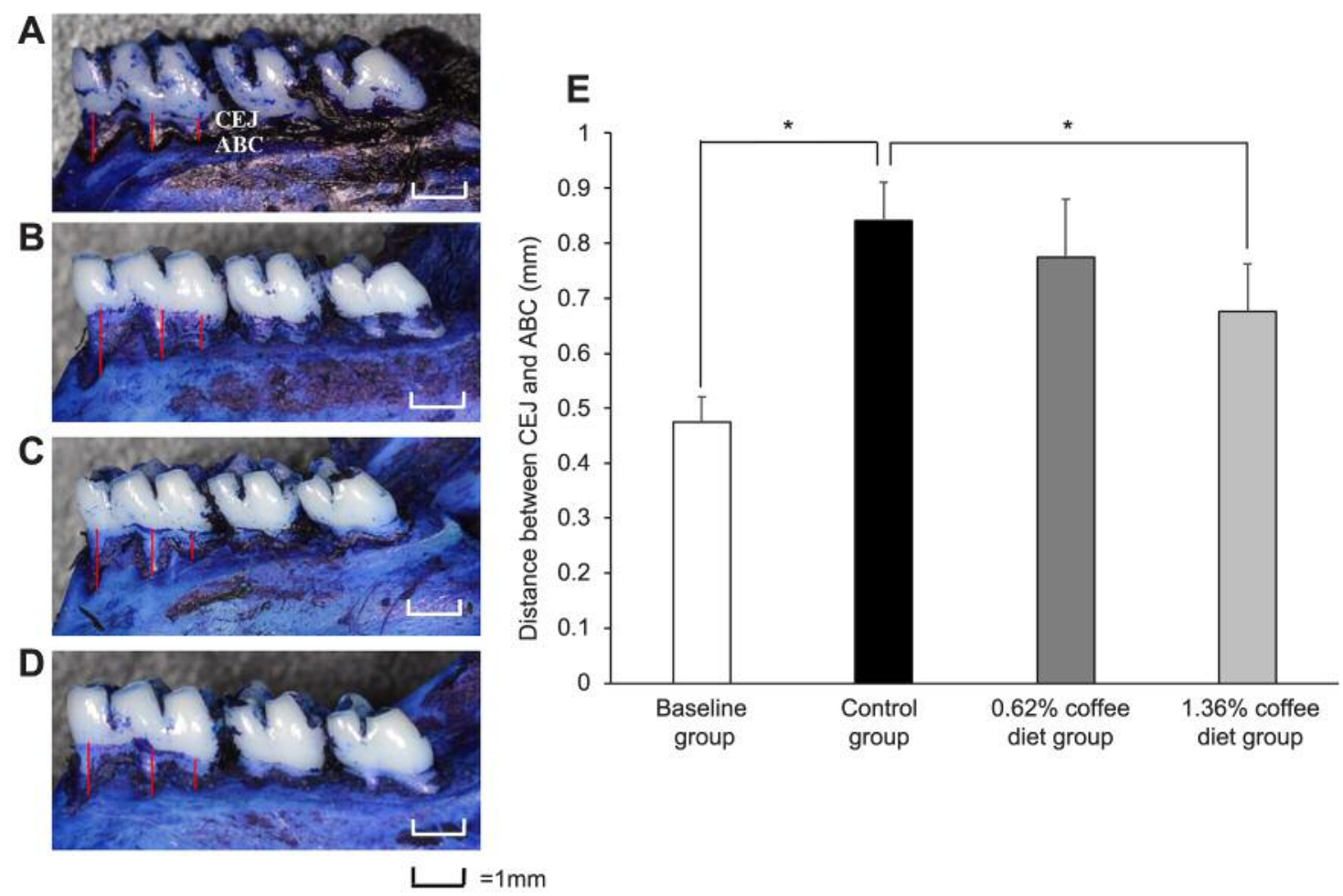

Figure 3. Alveolar bone loss (red lines) (A: Baseline group, B: Control group, C: $0.62 \%$ coffee diet group, D: $1.36 \%$ coffee diet group). Distance between the CEJ and the $A B C(E)$ Bars represent mean $\pm S D\left({ }^{*} p<0.05\right.$, according to one-way ANOVA followed by Tukey's method).

might suppress alveolar bone loss by inhibiting age-related oxidative stress in periodontal tissues.

High levels of the glutamate cysteine ligase modifier subunit, ferritin, and hypoxanthine phosphoribosyltransferase 1 genes were expressed in the $1.36 \%$ coffee group. Glutamate cysteine ligase modifier subunit is a rate-limiting enzyme in the synthesis of glutathione, which is the one of the most abundant intracellular antioxidants (31-33). Ferritin protects cells against iron-dependent oxidative stress and is involved in the regulation of oxidative stress $(34,35)$. These results suggest that continuous intake of coffee increased the antioxidant capacity of the periodontal tissue, which in turn might contribute to decreasing oxidative stress with aging in these tissues.

The redox-sensitive transcription factor, Nrf2, plays an important role in tissue antioxidant defense (36). Kelch-like ECH-associated protein 1 (Keap1) suppresses Nrf2 in the absence of oxidative stress (37). However, Nrf2 is released from repression mediated by Keap1 when exposed to oxidative stress and transferred into the nucleus to bind antioxidant response elements (38). The present study found more frequent Nrf2 nuclear translocation in the $1.36 \%$ coffee group than in the control group (Figure 4). These findings suggest that coffee enhances the antioxidant status of
Table I. List of the differentially expressed genes between the $1.36 \%$ coffee diet group and the control group.

\begin{tabular}{lc}
\hline Genes & Fold change \\
\hline Glutamate cysteine ligase, modifier subunit & 2.38 \\
Ferritin & 2.27 \\
Hypoxanthine phosphoribosyltransferase 1 & 2.23 \\
\hline
\end{tabular}

periodontal tissue by upregulating the Nrf2 signaling pathway. This notion is consistent with the previous finding that chlorogenic acid in coffee relieves oxidative stress associated with intestinal inflammation (39).

Coffee contains several antioxidant compounds. Among them, chlorogenic acid is a major coffee polyphenol with a powerful antioxidant capacity $(40,41)$. Chlorogenic acid significantly decreases malondialdehyde, a product of lipid peroxidation degradation, and significantly increases glutathione, superoxide dismutase and catalase in the livers and kidneys of mouse models of chronic injury (42). Chlorogenic acid inhibits malondialdehyde levels in the hippocampus and frontal cortex of mice (43). It remains 

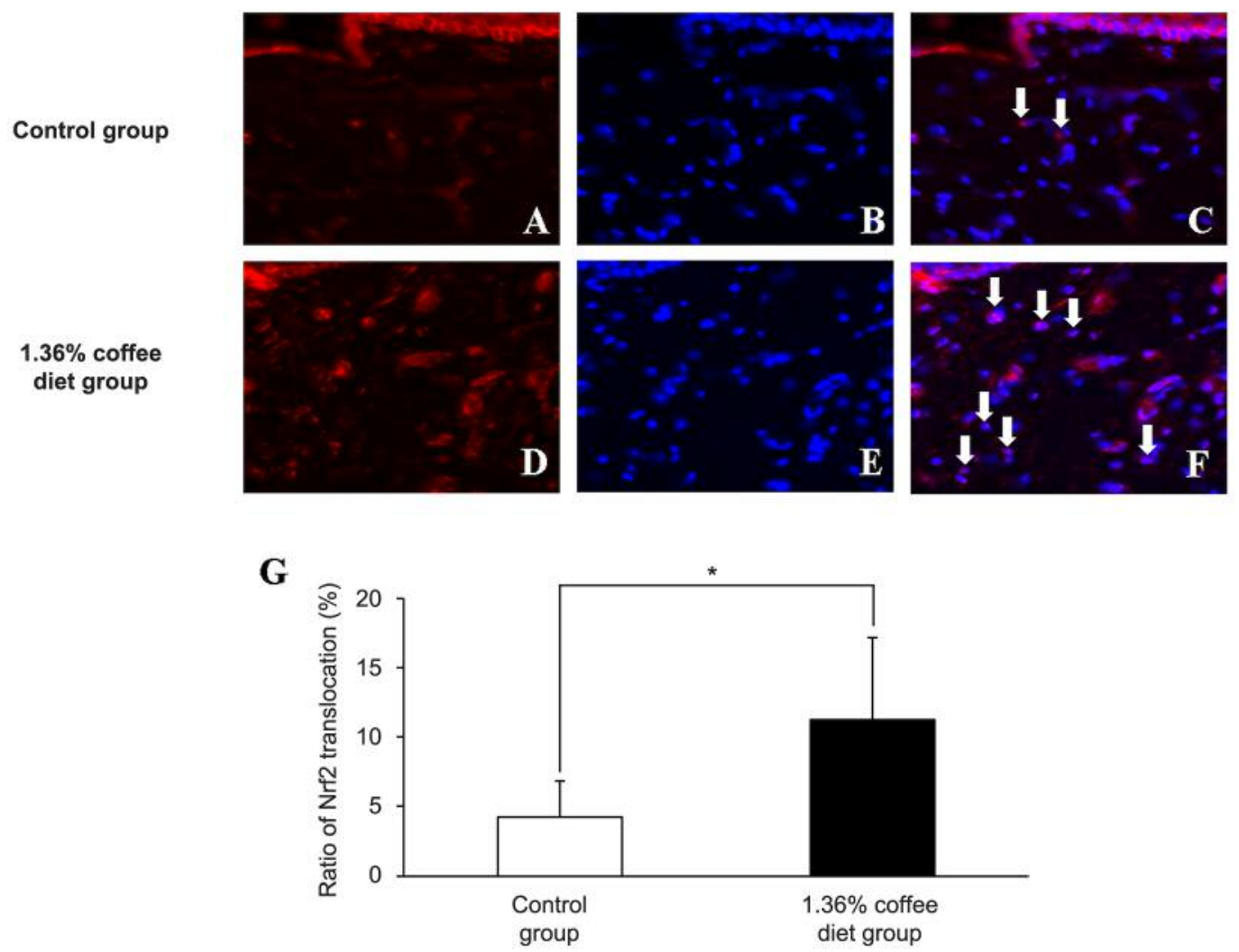

Figure 4. Translocation of Nrf2 to the nucleus (white arrows) $(C, F)$. The nuclear level of Nrf2 was determined using immunofluorescence staining $($ red $)(A, D)$. The cell nuclei were visualized by DAPI staining (blue) $(B, E)$. The ratios of Nrf2 translocation $(G)$. Bars represent mean $\pm S D(* p<0.05$, according to Student's t-test).

unclear whether the results of this study were actually due to chlorogenic acid. Nevertheless, the finding that coffee intake decreased periodontal oxidative damage is consistent with these previous results.

This study has certain limitations. Firstly, the experimental period was only 12 weeks. Therefore, the long-term anti-aging effects of coffee intake on oxidative stress in periodontal tissues and alveolar bone loss should be clarified. Also, we started to observe the effects of coffee intake using 8-weeksold rats. There might be different results when we use older rats. Secondary, this study examined changes in healthy periodontal tissue with increasing age and the effect of continuous coffee intake. The results of the effect of continuous coffee intake on periodontal disease might be different from those of this study. Thirdly, we focused on the anti-aging effect of coffee intake on oxidative stress in periodontal tissues, and did not consider changes in oral microorganisms. A previous study has shown that chlorogenic acid inhibits periodontogenic bacteria such as Porphyromonas gingivalis, Prevotella intermedia, Fusobacterium nucleatum and Aggregatibacter actinomycetemcomitans (44). Changes in periodontogenic microbiota with advancing age should be investigated.
In conclusion, continuous intake of $1.36 \%$ coffee prevented age-related oxidative stress in periodontal tissues and alveolar bone loss in rats, possibly by up-regulating the Nrf2 signaling pathway.

\section{Conflicts of Interest}

The Authors declare no conflicts of interest.

\section{Authors' Contributions}

Terumasa Kobayashi, Takayuki Maruyama, Tetsuji Azuma, Takaaki Tomofuji, Daisuke Ekuni and Manabu Morita conceived and designed the experiments; Terumasa Kobayashi, Hisataka Miyai and Tetsuji Azuma performed the experiments; Terumasa Kobayashi and Takayuki Maruyama analyzed the data; Terumasa Kobayashi, Takayuki Maruyama, Daisuke Ekuni, and Manabu Morita wrote the paper.

\section{Acknowledgements}

This research was supported by Grants-in-Aid for Scientific Research (grant numbers 26861830, 16K11855, and 16K20693) from the Ministry of Education, Culture, Sports, Science and Technology, Tokyo, Japan. 


\section{References}

1 Anton SD, Woods AJ, Ashizawa T, Barb D, Buford TW, Carter CS, Clark DJ, Cohen RA, Corbett DB, Cruz-Almeida Y, Dotson V, Ebner N, Efron PA, Fillingim RB, Foster TC, Gundermann DM, Joseph AM, Karabetian C, Leeuwenburgh C, Manini TM, Marsiske M, Mankowski RT, Mutchie HL, Perri MG, Ranka S, Rashidi P, Sandesara B, Scarpace PJ, Sibille KT, Solberg LM, Someya S, Uphold C, Wohlgemuth S, Wu SS, and Pahor M: Successful aging: Advancing the science of physical independence in older adults. Ageing Res Rev 24(Pt B): 304-327, 2015. PMID: 26462882. DOI: 10.1016/j.arr.2015.09.005

2 Kong Y, Trabucco SE and Zhang H: Oxidative stress, mitochondrial dysfunction and the mitochondria theory of aging Interdiscip Top Gerontol 39: 86-107, 2014. PMID: 24862016. DOI: $10.1159 / 000358901$

3 Wang L, He X, Szklarz GD, Bi Y, Rojanasakul Y and Ma Q: The aryl hydrocarbon receptor interacts with nuclear factor erythroid 2-related factor 2 to mediate induction of $\mathrm{NAD}(\mathrm{P}) \mathrm{H}$ : quinoneoxidoreductase 1 by 2,3,7,8-tetrachlorodibenzo-p-dioxin. Arch Biochem Biophys 537(1): 31-38, 2013. PMID: 23800876. DOI: $10.1016 /$ j.abb.2013.06.001

4 Chistiakov DA, Sobenin IA, Revin VV, Orekhov AN and Bobryshev YV: Mitochondrial aging and age-related dysfunction of mitochondria. Biomed Res Int 238463, 2014. PMID: 24818134. DOI: $10.1155 / 2014 / 238463$

5 Badr El-Din NK, Noaman E, Fattah SM, Ghoneum M: Reversal of age-associated oxidative stress in rats by MRN-100, a hydroferrate fluid. In Vivo 24(4): 525-533, 2010. PMID: 20668320.

6 López-Lluch G, Santos-Ocaña C, Sánchez-Alcázar JA, Fernández-Ayala DJ, Asencio-Salcedo C, Rodríguez-Aguilera JC and Navas P: Mitochondrial responsibility in ageing process: innocent, suspect or guilty. Biogerontology 16(5): 599-620, 2015. PMID: 26105157. DOI: 10.1007/s10522-015-9585-9

7 Grossi SG, Zambon JJ, Ho AW, Koch G, Dunford RG, Machtei EE, Norderyd OM and Genco RJ: Assessment of risk for periodontal disease. I. Risk indicators for attachment loss. J Periodontol 65(3): 260-267, 1994. PMID: 8164120. DOI:10.1902/ jop.1994.65.3.260

8 Chapple IL and Matthews JB: The role of reactive oxygen and antioxidant species in periodontal tissue destruction. Periodontol 2000 43: 160-232, 2007. PMID: 17214840. DOI: 10.1111/ j.1600-0757.2006.00178.x

9 Tamaki N, Tomofuji T, Maruyama T, Ekuni D, Yamanaka R, Takeuchi $\mathrm{N}$ and Yamamoto T: Relationship between periodontal condition and plasma reactive oxygen metabolites in patients in the maintenance phase of periodontal treatment. J Periodontol 79(11): 2136-2142, 2008. PMID: 18980522. DOI: 10.1902/ jop. 2008.080082

10 Tomofuji T, Azuma T, Kusano H, Sanbe T, Ekuni D, Tamaki N, Yamamoto $\mathrm{T}$ and Watanabe T: Oxidative damage of periodontal tissue in the rat periodontitis model: effects of a high-cholesterol diet. FEBS Lett 580(15): 3601-3604, 2006. PMID: 16750199 DOI: 10.1016/j.febslet.2006.05.041

11 Maruyama T, Tomofuji T, Endo Y, Irie K, Azuma T, Ekuni D, Tamaki N, Yamamoto T and Morita M: Supplementation of green tea catechins in dentifrices suppresses gingival oxidative stress and periodontal inflammation. Arch Oral Biol 56(1): 48-53, 2011 PMID: 20869695. DOI: 10.1016/j.archoralbio.2010.08.015
12 Azuma T, Yamane M, Ekuni D, Kawabata Y, Kataoka K, Kasuyama K, Maruyama T, Tomofuji T and Morita M: Drinking hydrogen-rich water has additive effects on non-surgical periodontal treatment of improving periodontitis: a pilot study. Antioxidants (Basel) 4(3): 513-522, 2015. PMID: 26783840. DOI: $10.3390 /$ antiox 4030513

13 Liang $\mathrm{N}$ and Kitts DD: Antioxidant property of coffee components: assessment of methods that define mechanisms of action. Molecules 19(11): 19180-19208, 2014. PMID: 25415479. DOI: $10.3390 /$ molecules 191119180

14 Budryn G, Zaczyńska D, Żyżelewicz D, Grzelczyk J, Zduńczyk $\mathrm{Z}$ and Juśkiewicz $\mathrm{J}$ : Influence of the form of administration of chlorogenic acids on oxidative stress induced by high fat diet in rats. Plant Foods Hum Nutr 72(2): 184-191, 2017. PMID: 28391410. DOI: $10.1007 / \mathrm{s} 11130-017-0608-3$

15 Machida T, Tomofuji T, Ekuni D, Azuma T, Takeuchi N, Maruyama T, Mizutani S, Kataoka K, Kawabata Y and Morita M: Severe periodontitis is inversely associated with coffee consumption in the maintenance phase of periodontal treatment. Nutrients 6(10): 4476-4490, 2014. PMID: 25338270. DOI: 10.3390/nu6104476

16 Han K, Hwang E and Park JB: Association between consumption of coffee and the prevalence of periodontitis: The 2008-2010 Korea National Health and Nutrition Examination survey. PLoS One 11(7): e0158845, 2016. PMID: 27387296. DOI: 10.1371/journal.pone.0158845

17 Bezerra JP, da Silva LR, de Alvarenga Lemos VA, Duarte PM and Bastos MF: Administration of high doses of caffeine increases alveolar bone loss in ligature-induced periodontitis in rats. J Periodontol 79(12): 2356-2360, 2008. PMID: 19053927. DOI: $10.1902 /$ jop.2008.080204

18 Bezerra JP, de Siqueira A, Pires AG, Marques MR, Duarte PM and Bastos MF: Effects of estrogen deficiency and/or caffeine intake on alveolar bone loss, density, and healing: a study in rats. J Periodontol 84(6): 839-849, 2013. PMID: 22873654. DOI: 10.1902/jop.2012.120192

19 Sakamoto W, Isomura H, Fujie K, Takahashi K, Nakao K and Izumi H: Relationship of coffee consumption with risk factors of atherosclerosis in rats. Ann Nutr Metab 49(3): 149-154, 2005. PMID: 15942160 . DOI: 10.1159/000086170

20 Tamaki N, Tomofuji T, Ekuni D, Yamanaka R and Morita M: Periodontal treatment decreases plasma oxidized LDL level and oxidative stress. Clin Oral Investig 15(6): 953-958, 2011. PMID: 20717698. DOI: 10.1007/s00784-010-0458-y

21 Kasai H: Chemistry-based studies on oxidative DNA damage: formation, repair, and mutagenesis. Free Radic Biol Med 33(4): 450-456, 2002. PMID: 12160927.

22 Ekuni D, Tomofuji T, Yamanaka R, Tachibana K, Yamamoto T and Watanabe T: Initial apical migration of junctional epithelium in rats following application of lipopolysaccharide and proteases. $\mathrm{J}$ Periodontol 76(1): 43-48, 2005. PMID: 15830636. DOI: 10.1902/ jop.2005.76.1.43

23 Kim MH, Choi YY, Lee HJ, Lee H, Park JC and Yang WM: Topical application of herbal formula for the treatment of ligatureinduced periodontitis. J Periodontal Implant Sci 45(4): 145-151, 2015. PMID: 26339524. DOI: 10.5051/jpis.2015.45.4.145

24 Hjelmeland LM, Fujikawa A, Oltjen SL, Smit-McBride Z and Braunschweig D: Quantification of retinal pigment epithelial phenotypic variation using laser scanning cytometry. Mol Vis 16 : 1108-1121, 2010. PMID: 20606706. 
25 Neria F, Castilla MA, Sanchez RF, Gonzalez Pacheco FR, Deudero JJ, Calabia O, Tejedor A, Manzarbeitia F, Ortiz A and Caramelo C: Inhibition of JAK2 protects renal endothelial and epithelial cells from oxidative stress and cyclosporin A toxicity. Kidney Int 75(2): 227-234, 2009. PMID: 18818682. DOI: 10.1038/ki.2008.487

26 Tomofuji T, Kawabata Y, Kasuyama K, Endo Y, Yoneda T, Yamane M, Azuma T, Ekuni D and Morita M: Effects of hydrogen-rich water on aging periodontal tissues in rats. Sci Rep 4: 5534, 2014. PMID: 24985521. DOI: 10.1038/srep05534

27 Sanbe T, Tomofuji T, Ekuni D, Azuma T, Tamaki $\mathrm{N}$ and Yamamoto T: Oral administration of vitamin C prevents alveolar bone resorption induced by high dietary cholesterol in rats. J Periodontol 78(11): 2165-2170, 2007. PMID: 17970684. DOI: 10.1902/jop.2007.070181

28 Ohnishi T, Bandow K, Kakimoto K, Machigashira M, Matsuyama $\mathrm{T}$ and Matsuguchi $\mathrm{T}$ : Oxidative stress causes alveolar bone loss in metabolic syndrome model mice with type 2 diabetes. J Periodontal Res 44(1): 43-51, 2009. PMID: 18973548. DOI: 10.1111/j.1600-0765.2007.01060.x

29 Aguirre J, Buttery L, O'Shaughnessy M, Afzal F, Fernandez de Marticorena I, Hukkanen M, Huang P, MacIntyre I and Polak J: Endothelial nitric oxide synthase gene-deficient mice demonstrate marked retardation in postnatal bone formation, reduced bone volume, and defects in osteoblast maturation and activity. Am J Pathol 158(1): 247-257, 2001. PMID: 11141498. DOI: $10.1016 /$ S0002-9440(10)63963-6

30 Armour KE, Armour KJ, Gallagher ME, Gödecke A, Helfrich MH, Reid DM and Ralston SH: Defective bone formation and anabolic response to exogenous estrogen in mice with targeted disruption of endothelial nitric oxide synthase. Endocrinology 142(2): 760766, 2001. PMID: 11159848. DOI: 10.1210/endo.142.2.7977

31 Lim J, Nakamura BN, Mohar I, Kavanagh TJ and Luderer U: Glutamate cysteine ligase modifier subunit ( $\mathrm{Gclm})$ null mice have increased ovarian oxidative stress and accelerated agerelated ovarian failure. Endocrinology 156(9): 3329-3343, 2015. PMID: 26083875. DOI: 10.1021/acs.jafc.8b03983

32 Franklin CC, Backos DS, Mohar I, White CC, Forman HJ and Kavanagh TJ: Structure, function, and post-translational regulation of the catalytic and modifier subunits of glutamate cysteine ligase. Mol Aspects Med 30(1-2): 86-98, 2009. PMID: 18812186. DOI: 10.1016/j.mam.2008.08.009

33 Griffith OW and Mulcahy RT: The enzymes of glutathione synthesis: $\gamma$-glutamylcysteine synthetase. Adv Enzymol Relat Areas Mol Biol 73: 209-267, 1999. PMID: 10218110.

34 Eisenstein RS, Garcia-Mayol D, Pettingell W and Munro HN: Regulation of ferritin and heme oxygenase synthesis in rat fibroblasts by different forms of iron. Proc Natl Acad Sci USA 88(33): 688692, 1991. PMID: 1992460. DOI: 10.1073/pnas.88.3.688

35 Balla G, Jacob HS, Balla J, Rosenberg M, Nath K, Apple F, Eaton JW and Vercellotti GM: Ferritin: a cytoprotective antioxidant strategem of endothelium. J Biol Chem 267(25): 18148-18153, 1992. PMID: 1517245

36 Hintsala HR, Jokinen E, Haapasaari KM, Moza M, Ristimäki A, Soini Y, Koivunen J and Karihtala P: Nrf2/Keap1 pathway and expression of oxidative stress lesions 8-hydroxy-2'-deoxyguanosine and nitrotyrosine in melanoma. Anticancer Res 36(4): 1497-1506, 2016. PMID: 27069125.
37 Itoh K, Wakabayashi N, Katoh Y, Ishii T, Igarashi K, Engel JD and Yamamoto M: Keap1 represses nuclear activation of antioxidant responsive elements by Nrf2 through binding to the amino-terminal Neh2 domain. Genes Dev 13(1): 76-86, 1999. PMID: 9887101. DOI: 10.1101/gad.13.1.76

38 Takagi T, Kitashoji A, Iwawaki T, Tsuruma K, Shimazawa M, Yoshimura S, Iwama T and Hara H: Temporal activation of Nrf2 in the penumbra and $\mathrm{Nrf} 2$ activator-mediated neuroprotection in ischemia-reperfusion injury. Free Radic Biol Med 72: 124-133, 2014. PMID: 24746614. DOI: 10.1016/j.freeradbiomed.2014. 04.009

39 Liang N and Kitts DD: Amelioration of oxidative stress in Caco2 cells treated with pro-inflammatory proteins by chlorogenic acid isomers via activation of the Nrf2-Keap1-ARE-signaling pathway. J Agric Food Chem 66(42): 11008-11017, 2018. PMID: 30259744. DOI: $10.1021 /$ acs.jafc.8b03983

40 Tajik N, Tajik M, Mack I and Enck P: The potential effects of chlorogenic acid, the main phenolic components in coffee, on health: a comprehensive review of the literature. Eur J Nutr 56(7): 2215-2244, 2017. PMID: 28391515. DOI: 10.1007/ s00394-017-1379-1

41 Yang JS, Liu CW, Ma YS, Weng SW, Tang NY, Wu SH, Ji BC, Ma CY, Ko YC, Funayama S and Kuo CL: Chlorogenic acid induces apoptotic cell death in U937 leukemia cells through caspase- and mitochondria-dependent pathways. In Vivo 26(6): 971-978, 2012. PMID: 23160680.

42 Feng Y, Yu YH, Wang ST, Ren J, Camer D, Hua YZ, Zhang Q, Huang J, Xue DL, Zhang XF, Huang XF and Liu Y: Chlorogenic acid protects D-galactose-induced liver and kidney injury via antioxidation and anti-inflammation effects in mice. Pharm Biol 54(6): 1027-1034, 2016. PMID: 26810301. DOI: 10.3109/ 13880209.2015.1093510

43 Kwon SH, Lee HK, Kim JA, Hong SI, Kim HC, Jo TH, Park YI, Lee CK, Kim YB, Lee SY and Jang CG: Neuroprotective effects of chlorogenic acid on scopolamine-induced amnesia via antiacetylcholinesterase and anti-oxidative activities in mice. Eur J Pharmacol 649(1-3): 210-217, 2010. PMID: 20854806. DOI: 10.1016/j.ejphar.2010.09.001

44 Bharath N, Sowmya NK and Mehta DS: Determination of antibacterial activity of green coffee bean extract on periodontogenic bacteria like Porphyromonas gingivalis, Prevotella intermedia, Fusobacterium nucleatum and Aggregatibacter actinomycetemcomitans: An in vitro study. Contemp Clin Dent 6(2): 166-169, 2015. PMID: 26097349. DOI: 10.4103/0976237X.156036 